\title{
Palladium-Catalyzed Arylation of Enoates with Iodobenzene: Stereoselective Synthesis of Trisubstituted Olefins
}

\author{
Talita de A. Fernandes, ${ }^{a, b}$ Boniek G. Vaz, ${ }^{c, d}$ Alcides J. M. da Silva, ${ }^{a}$ \\ Pierre M. Esteves, ${ }^{b}$ Marcos N. Eberlin, ${ }^{*, c}$ and Paulo R. R. Costa ${ }^{*, a}$ \\ ${ }^{a}$ Laboratório de Química Bioorgânica (LQB), Núcleo de Pesquisas de Produtos Naturais, \\ Centro de Ciências da Saúde, Bloco H, Ilha da Cidade Universitária, \\ Universidade Federal do Rio de Janeiro, 21941-590 Rio de Janeiro-RJ, Brazil \\ ${ }^{b}$ Interlab, Instituto de Química, Universidade Federal do Rio de Janeiro, \\ 21945-470 Rio de Janeiro-RJ, Brazil \\ ${ }^{c}$ Laboratório ThoMSon de Espectrometria de Massas, Instituto de Química, \\ Universidade Estadual de Campinas, 13083-970 Campinas-SP, Brazil \\ 'Instituto de Química, Universidade Federal de Goiás, Campus Samambaia, \\ CP 131, CEP 74001-970, Goiânia, GO, Brazil
}

\begin{abstract}
A reação de Heck entre enoatos de configuração $Z$ e $E$ e o iodobenzeno foi estudada na presença de $\mathrm{Pd}(\mathrm{OAc})_{2}$. A estereoquímica nos adutos formados foi dependente da geometria do enoato (reação estereoespecífica). Os melhores rendimentos foram obtidos a partir de enoatos $Z$, em acetona, utilizando $\mathrm{Ag}_{2} \mathrm{CO}_{3}$ como base. Os principais intermediários catiônicos de paládio possivelmente envolvidos no ciclo catalítico puderam ser interceptados e caracterizados por espectrometria de massas com ionização electrospray (ESI-MS). A estereosseletividade observada pôde ser racionalizada através do mecanismo clássico da reação de Heck.
\end{abstract}

The Heck reaction between $E$ - and $Z$-enoates and iodobenzene was studied in the presence of $\mathrm{Pd}(\mathrm{OAc})_{2}$. The stereochemistry in resulting adducts was dependent on the enoate geometry (stereospecific reaction). Best yields were obtained from $Z$-isomers in acetone using $\mathrm{Ag}_{2} \mathrm{CO}_{3}$ as base. The main cationic palladium intermediates possibly involved in the catalytic cycle could be intercepted and characterized by electrospray ionization mass spectrometry (ESI-MS). The stereoselectivity observed was rationalized through the classic mechanism of the Heck reaction.

Keywords: Heck reaction, enoates, palladium catalysis, mass spectrometry

\section{Introduction}

Heck and collaborators described in 1968 the preparation of methyl cinnamate by the reaction of phenylmercuric chloride with methyl acrylate in the presence of stoichiometric amounts of $\mathrm{PdCl}_{2} / \mathrm{LiCl}^{1}$ Mizoroki, et al. in $1971^{2}$ and Heck and Nolley in $1972^{3}$ reported the arylation of styrene by iodobenzene in the presence of catalytic amounts of palladium salts. Since then, the scope of the Heck reaction has been extensively expanded and new sources of organopalladium species as well as new types of olefins have been incorporated into the set of starting materials suitable for this reaction., ${ }^{4,5}$

*e-mail: eberlin@iqm.unicamp.br, prrcosta2011@gmail.com
Intramolecular Heck reaction allows the preparation of heterocycles and molecules bearing tertiary and quaternary centers, via carbopalladation of 1,2-disubstituted and trisubstituted double bonds. ${ }^{6}$ In contrast, we found scattered examples involving the intermolecular Heck reaction of conjugate double bond bearing substituents at the $\beta$-position, such as crotonates and cinnamates.?

Stereoselective synthesis of 1,2 disubstituted olefins is a well established process and these products can be synthesized via Wittig-type reactions, ${ }^{8}$ using organometallics ${ }^{9}$ and more recently by metathesis. ${ }^{10}$ In contrast, stereocontrol in construction of trisubstituted olefins remains a challenge. ${ }^{11}$

In this article we report stereoselective arylation of a series of enoates with iodobenzene. These reactions were studied under classical Heck conditions, ${ }^{3}$ in which the 
neutral mechanism is favored and the results are compared with those obtained in conditions favoring the cationic mechanism (in the presence of $\mathrm{Ag}_{2} \mathrm{CO}_{3}$ or using water as solvent). ${ }^{4,12} \mathrm{~A}$ mechanistic rationalization was proposed based on electrospray ionization mass spectrometry (ESI-MS) monitoring.

\section{Results and Discussion}

In contrast to acrylates, which under classical Heck conditions (neutral mechanism) are known to react with iodobenzene (2) leading to cinnamates in good yields, ${ }^{3,13}$ enoate $Z-\mathbf{1}$ furnished only traces of adduct $E-3$ in the presence of $\mathrm{Pd}(\mathrm{OAc})_{2}, \mathrm{PPh}_{3}, \mathrm{Et}_{3} \mathrm{~N}$ and $\mathrm{DMF}$ (Dimethylformamide) at $70{ }^{\circ} \mathrm{C}$ for $40 \mathrm{~h}$ (Scheme 1, Table 1, entry 1). Yield of $E-\mathbf{3}$ did not increase when Z-1 and 2 were allowed to react under reflux in this solvent, leading to extensive isomerization from $Z-\mathbf{1}$ to $E-\mathbf{1}$ (data not showed). Enoate $E-1$ was completely recovered when allowed to react under these conditions (entry 2). Due to these disappointing results, we decided to try reaction conditions that would favor the cationic mechanism, using silver salts as bases. Indeed, the yield of $E-\mathbf{3}$ obtained from $\mathrm{Z}-\mathbf{1}$ increased to $71 \%$ in the presence of $\mathrm{Ag}_{2} \mathrm{CO}_{3}, \mathrm{PPh}_{3}$ and acetone (entry 3) and higher yield (79\%) was obtained in the absence of $\mathrm{PPh}_{3}$ (entry 4). Reaction times could not be reduced without decrease in yields. An excess of enoate is necessary but it can be recovered in the reaction purification. Enoate $E-\mathbf{1}$ was much less reactive than Z-1 under these same conditions, leading to adduct Z-3 in moderate yield (entry 5). This difference in chemical reactivity between $Z-\mathbf{1}$ and $E-\mathbf{1}$ suggest that the transition state for the carbopalladation step of Z-1 is sterically less hindered. Since it has been accepted that Heck reactions in water also proceed through a cationic mechanism, ${ }^{4,12}$ these reactions were also studied in water using $\mathrm{Pd}(\mathrm{OAc})_{2}$ and $\mathrm{Et}_{3} \mathrm{~N}$. In contrast with Heck-lactonization reactions with enoate $Z-\mathbf{1}$, which proceeds quite well in aqueous medium, ${ }^{12}$ the yields of Heck reaction between Z-1 and $\mathbf{2}$ decreased in water. Cinnamate $E-\mathbf{3}$ was obtained in $48 \%$ yield from $Z-1$ (entry 6), while $E-\mathbf{1}$ furnished $Z-\mathbf{3}$ in only $18 \%$ yield (entry 7). These reactions were stereospecific and only one geometric isomer was observed in crude spectra.

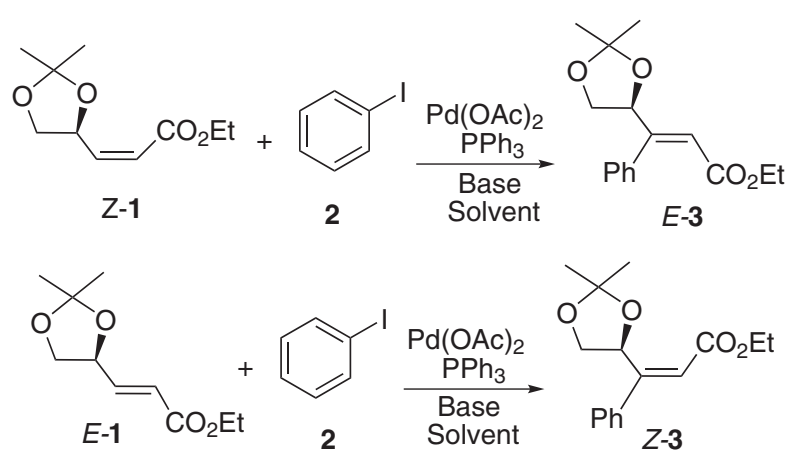

Scheme 1. Palladium catalyzed reaction between iodobenzene 2 and olefins $Z-1$ and $E-1$.

To further evaluate the scope of this Heck reaction, a few other enoates were selected to react with $\mathbf{2}$ (Scheme 2, Table 2). Methyl maleate (Z-4) led to adduct $E-8$ in $63 \%$ yield whereas its isomer $Z-8$ was obtained from $E-4$ in $35 \%$ yield (Scheme 2, Table 2, entries 1 and 2). Kondolff co-workers ${ }^{7}$ described a mixture of stereoisomers in which the geometry of preferential product was independent on the starting material geometry in the reaction of these olefins with iodobenzene using a tedicyp-palladium complex in DMF. ${ }^{7}$ Methyl maleate (Z-4) produced the corresponding adduct in worse yields than $Z-\mathbf{1}$ but in better yields than its isomer $E$-4. Only traces of the corresponding geometric isomers were observed in the purified products (they not appeared in crude mixtures). Adduct 9 was obtained from 5 in $40 \%$ yield in the presence of $\mathrm{Ag}_{2} \mathrm{CO}_{3}$ but only $14 \%$ yield was obtained in water (entries 3 and 4). Methyl crotonate (6) and methyl cinnamate (7) led to the corresponding adducts $\mathbf{1 0}$ and $\mathbf{1 1}$, respectively, in poor yields (entries 5, 6 and 7). ${ }^{14}$

Table 1. Yields and major conditions for the reactions shown in Scheme 1

\begin{tabular}{|c|c|c|c|c|c|c|}
\hline Entry & Olefin & Base & $\mathrm{PPh}_{3}$ & Solvent & Product & $\% 3^{a}$ \\
\hline $1^{\mathrm{b}}$ & $Z-1$ & $\mathrm{Et}_{3} \mathrm{~N}$ & $20 \mathrm{~mol} \%$ & DMF & $E-\mathbf{3}$ & Traces \\
\hline $2^{\mathrm{b}}$ & $E-1$ & $\mathrm{Et}_{3} \mathrm{~N}$ & $20 \mathrm{~mol} \%$ & DMF & \multicolumn{2}{|c|}{ no reaction } \\
\hline $3^{c}$ & $Z-1$ & $\mathrm{Ag}_{2} \mathrm{CO}_{3}$ & $20 \mathrm{~mol} \%$ & Acetone & $E-3$ & 71 \\
\hline $4^{c}$ & $Z-1$ & $\mathrm{Ag}_{2} \mathrm{CO}_{3}$ & absence & Acetone & $E-3$ & 79 \\
\hline $5^{c}$ & $E-1$ & $\mathrm{Ag}_{2} \mathrm{CO}_{3}$ & $20 \mathrm{~mol} \%$ & Acetone & $Z-3$ & 44 \\
\hline $6^{\mathrm{d}}$ & $Z-1$ & $\mathrm{Et}_{3} \mathrm{~N}$ & absence & $\mathrm{H}_{2} \mathrm{O}$ & $E-3$ & 48 \\
\hline $7^{\mathrm{d}}$ & $E-1$ & $\mathrm{Et}_{3} \mathrm{~N}$ & absence & $\mathrm{H}_{2} \mathrm{O}$ & $Z-3$ & 18 \\
\hline
\end{tabular}

Reaction mixtures were heated for $40 \mathrm{~h}$ in the presence of $10 \mathrm{~mol} \%$ of $\mathrm{Pd}(\mathrm{OAc})_{2}, 20 \mathrm{~mol} \% \mathrm{PPh}_{3}$ and 3 equiv of base. ${ }^{\mathrm{a}}$ Isolated yields; ${ }^{\mathrm{b}} \mathrm{Reactions} \mathrm{in} \mathrm{DMF}$

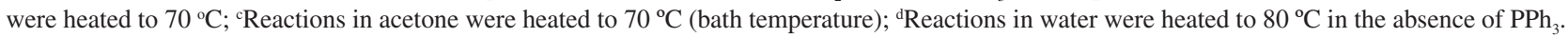



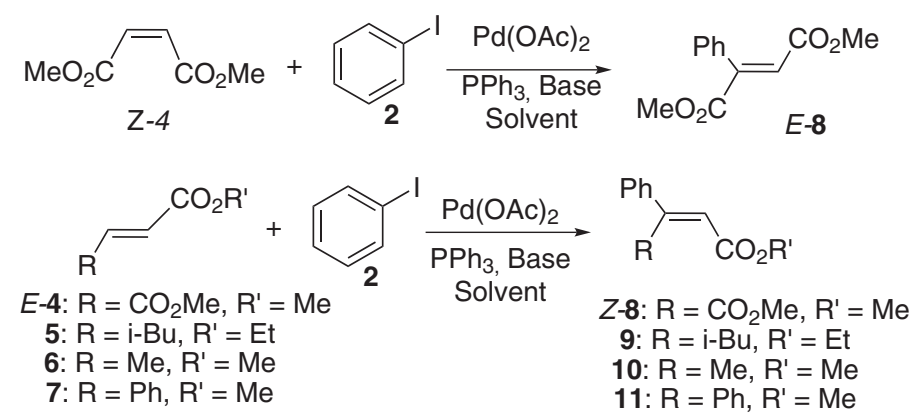

Scheme 2. Palladium catalyzed reaction between iodobenzene $\mathbf{2}$ and olefins $\mathbf{4}$ to $\mathbf{7}$.

Table 2. Yields and conditions for the reactions shown in Scheme 2

\begin{tabular}{|c|c|c|c|c|c|c|}
\hline Entry & Olefin & Base & $\mathrm{PPh}_{3}$ & Solvent & Product & $\%^{\mathrm{a}}$ \\
\hline 1 & $Z-4$ & $\mathrm{Ag}_{2} \mathrm{CO}_{3}$ & $20 \mathrm{~mol} \%$ & Acetone & E-8 & 63 \\
\hline 2 & $E-4$ & $\mathrm{Ag}_{2} \mathrm{CO}_{3}$ & $20 \mathrm{~mol} \%$ & Acetone & Z-8 & 35 \\
\hline 3 & 5 & $\mathrm{Ag}_{2} \mathrm{CO}_{3}$ & $20 \mathrm{~mol} \%$ & Acetone & 9 & 40 \\
\hline $4^{\mathrm{b}, \mathrm{c}}$ & 5 & $\mathrm{Et}_{3} \mathrm{~N}$ & absence & $\mathrm{H}_{2} \mathrm{O}$ & 9 & 14 \\
\hline 5 & 6 & $\mathrm{Ag}_{2} \mathrm{CO}_{3}$ & $20 \mathrm{~mol} \%$ & Acetone & 10 & 26 \\
\hline 6 & 7 & $\mathrm{Ag}_{2} \mathrm{CO}_{3}$ & $20 \mathrm{~mol} \%$ & Acetone & 11 & 33 \\
\hline $7^{\mathrm{a}}$ & 7 & $\mathrm{Et}_{3} \mathrm{~N}$ & absence & $\mathrm{H}_{2} \mathrm{O}$ & 11 & 19 \\
\hline
\end{tabular}

Reaction mixtures were heated to $70{ }^{\circ} \mathrm{C}$ for $40 \mathrm{~h}$ in the presence of $10 \mathrm{~mol} \%$ of $\mathrm{Pd}(\mathrm{OAc})_{2}, 20 \mathrm{~mol} \% \mathrm{PPh}_{3}$ and 3 equiv of base. ${ }^{\text {IIsolated yields; }}{ }^{\mathrm{b} R e a c t i o n s}$ in water were heated to $80{ }^{\circ} \mathrm{C} ;{ }^{\circ} \mathrm{PdCl}_{2}$ used as catalyst.

The configuration at the double bond in $\mathbf{3}$ was established by nOe experiments (Figure 1). Irradiation at the olefinic hydrogen of $E-\mathbf{3}$ (in red) led to enhanced signals for one of the methyl group at the dioxolane ring and hydrogen at chiral center (Figure 1a). Similarly, irradiation at this methyl group (in red, Figure 1b) led to enhanced signals for the other geminal methyl group, one hydrogen at the dioxolane ring, olefinic hydrogen and hydrogen attached at the chiral center. As expected, for NOE experiments with Z-3 no interference was observed in olefinic proton after irradiation at methyl groups at the dioxolane ring (Figure $1 \mathrm{c}$ and $1 \mathrm{~d}$ ). Configuration of $Z-8$ and $E-8$ were established by comparison with literature data. ${ }^{15}$ Products $\mathbf{9 , 1 0}$ and $\mathbf{1 1}$ are also described. ${ }^{16}$

DFT (Density Functional Theory) calculations at M06-2X/6-311++G(d,p) level were carried out to confirm the NOE interpretation. Geometries of Z-3 and $E-\mathbf{3}$ were fully optimized at this level and characterized as minimum on the potential energy surface by the absence of imaginary frequencies after vibrational analysis. Figure 2 shows the optimized geometries showing some selected distances. All calculations were made with the Gaussian 09 package. ${ }^{17}$ The intermolecular distances shown confirm the assignment made by the nOe experiments.

It was also performed an investigation of the mechanism of enoate arylations via direct infusion electrospray a) Adduct E-3, irradiation at $6.29 \mathrm{ppm}$

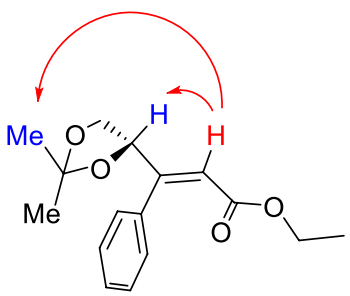

c) Adduct Z-3, irradiation at $1.37 \mathrm{ppm}$

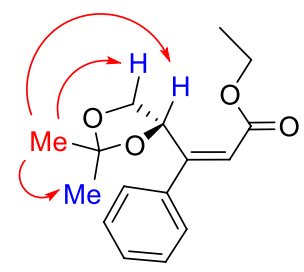

b) Adduct E-3 irradiation at $1.46 \mathrm{ppm}$

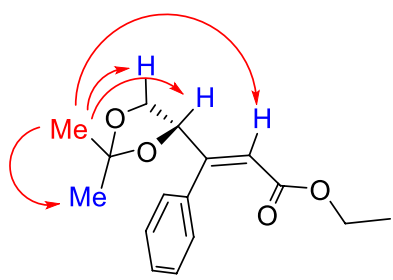

d) Adduct Z-3, irradiation at $1.21 \mathrm{ppm}$

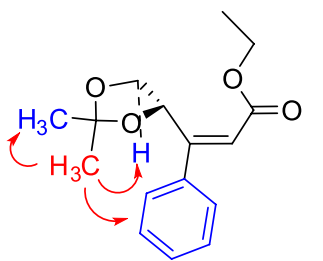

Figure 1. Stereochemistry assignments by NOE experiments; (a) adduct $E-\mathbf{3}$, (b) adduct $E-\mathbf{3}$, (c) adduct $Z-3$, (d) adduct $Z-\mathbf{3}$.

ionization mass spectrometry (ESI-MS) monitoring and its tandem version (ESI-MS/MS).$^{18}$ This technique has become a major tool for mechanistic studies in organic and inorganic chemistry owing to its outstanding ability to "fish" ionic or ionized intermediates directly from reaction solutions into the gas phase with high sensitivity, speed, 

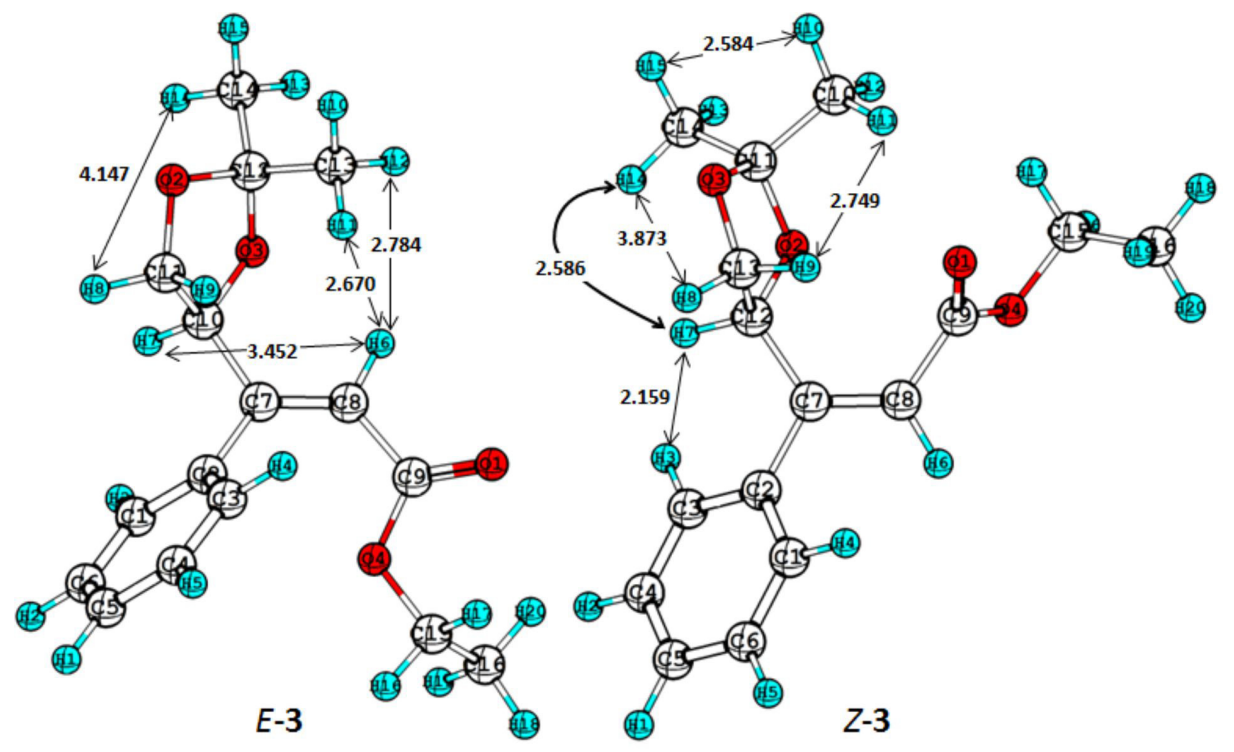

Figure 2. Optimized geometries of the $E$ and $Z$ forms of the adduct 3 .

and gentleness. The mechanism of Heck reactions has also been the subject of extensive investigation via ESI-MS. ${ }^{12,19}$ Samples of the reaction solution were diluted in $\mathrm{MeCN}$ before recording the MS data.

As expected, cationic palladium species could be intercepted in Heck reaction between Z-1 and $\mathbf{2}$ in presence or absence of phosphines. Figure 3 shows some intermediates formed in oxidative addition and migratory insertion steps. The structures of these cationic species were confirmed by the characteristic Pd multi-isotopic pattern (only the $\mathrm{m} / \mathrm{z}$ of the most abundant isotopologue ion is mentioned) and by ESI-MS/MS (supplementary information).

Based on the ESI-MS data and in the observed stereoselectivity, it was rationalized a mechanism for the Heck reaction between $\mathbf{1}$ and $\mathbf{2}$ in the presence of $\mathrm{Ag}_{2} \mathrm{CO}_{3}$

(a) Oxidative addition intermediates:

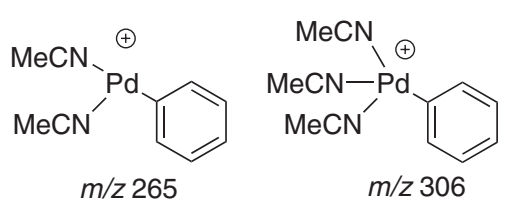

(b) Migratory insertion intermediates:

(Scheme 3). The cationic phenyl palladium $\mathbf{1 2}$ is firstly formed, reacting subsequently with Z-1 via a regio and syn-stereoselective carbopalladation, to form the key cationic intermediate 13. Syn-elimination of $\mathrm{HPd}^{+}$from 13 (conformer $\mathrm{C}_{2}$ ) leads stereoselectively to adduct $E-\mathbf{3}$ (Scheme 3a) ${ }^{4,5}$ Similarly, Z-3 is formed when $E-\mathbf{1}$ is used as the olefin (Scheme 3b).

\section{Conclusions}

This study has shown that $Z$-enoates are better substrates for the Heck reaction than $E$-enoates, which are more sterically hindered. The use of such enoates allowed the stereospecific synthesis of isomeric $\beta$-substituted cinnamates. These present results are in contrast with those previously reported for Heck reactions of cinnamates with

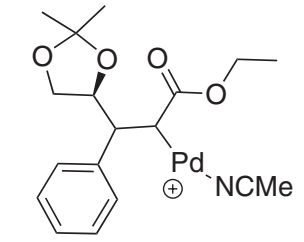

$m / z 424$

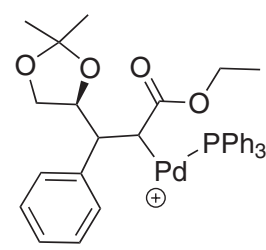

$m / z 645$

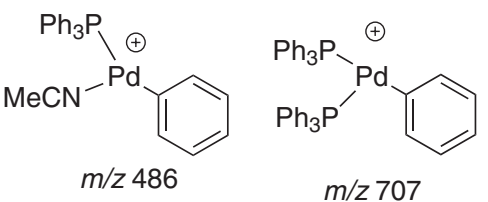

$m / 2707$

Figure 3. Some detected intermediates on ESI(+)-MS of the reaction solution of Z-1 and 2; (a) oxidative addition intermediates, (b) migratory insertion intermediates. 
(a)

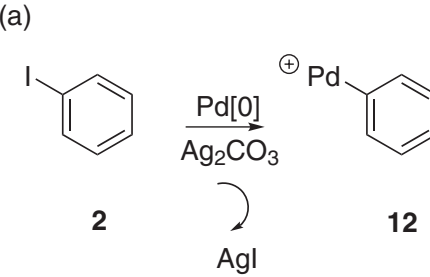<smiles>CCOC(=O)C=CC1COC(C)(C)O1</smiles>

2<smiles>[R]C([18OH])[C@@H]([18OH])c1ccccc1</smiles>

$13\left(C_{1}\right)$

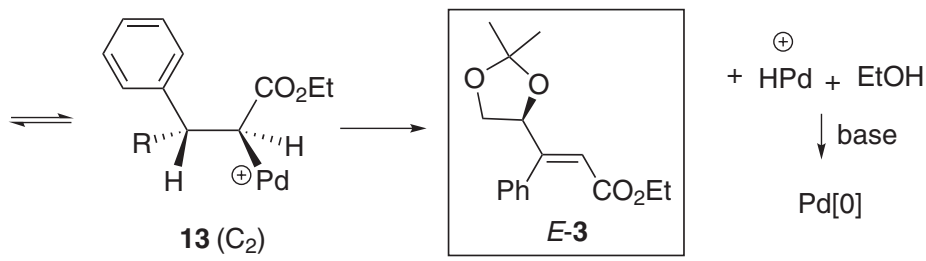

(b)

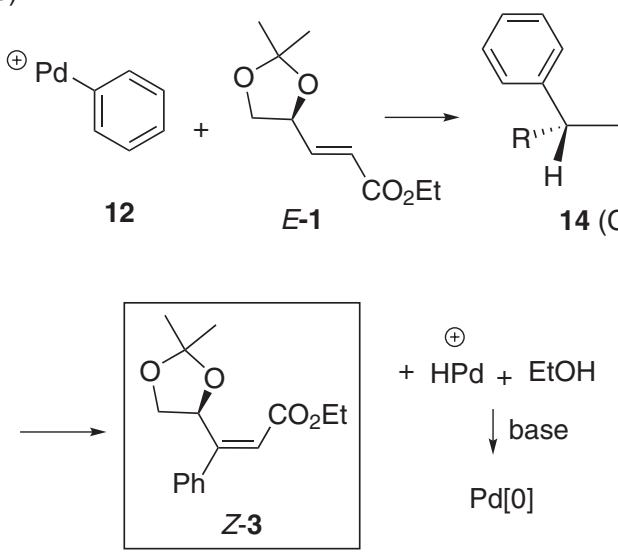

Scheme 3. Proposed mechanism for the Heck reaction between enoates $Z-\mathbf{1}$ (a) and $E-\mathbf{1}$ (b) with $\mathbf{2}$ in the presence of $\mathrm{Ag}_{2} \mathrm{CO}_{3}$.

haloarenes, in which the stereochemistry in the adducts is defined by isomerisation of products via thermodynamic control. ${ }^{4}$ The results are also in contrast with those previously reported for Heck reactions of maleates and fumarates with iodobenzene, in which a mixture of isomeric products was formed. ${ }^{7}$ Although it was used a limited number of variations, further studies with a large set olefins and iodoarens must be accomplished to confirm the suitability of this stereoselective methodology as an important tool to synthesize trisubstituted olefins.

\section{Experimental}

\section{General procedure of ESI-MS and ESI-MS/MS}

All experiments were performed on a hybrid quadrupole time-of-flight mass spectrometer (Q-TOF, Waters). For typical electrospray ionization (ESI) conditions, the Teflonsealed microsyringe was put in a pump that delivered the reagent solution into the ESI source at a flow rate of
$10 \mu \mathrm{L} \mathrm{m^{-1 }}$. ESI and the mass spectrometer was operated in the positive ion mode. Main conditions were capillary voltage, $3500 \mathrm{eV}$; cone voltage, $35 \mathrm{eV}$; source temperature, $100{ }^{\circ} \mathrm{C}$; desolvation temperature, $100^{\circ} \mathrm{C}$. The cationic species were subjected to collision-induced dissociation (CID) with argon by using collision energies ranging from 5 to $45 \mathrm{eV}$.

Cinnamates 3, 8, 9, 10 and 11; General procedure in organic solvents

A mixture of iodobenzene $(2,102 \mathrm{mg}, 0.5 \mathrm{mmol})$, enoate $(Z-1,300 \mathrm{mg}, 1.5 \mathrm{mmol}), \mathrm{Pd}(\mathrm{OAc})_{2}(11.2 \mathrm{mg}$, $0.05 \mathrm{mmol}), \mathrm{PPh}_{3}(26.2 \mathrm{mg}, 0.1 \mathrm{mmol}), \mathrm{Ag}_{2} \mathrm{CO}_{3}(414 \mathrm{mg}$, $1.5 \mathrm{mmol})$ and acetone $(15 \mathrm{~mL})$ was stirred at $70{ }^{\circ} \mathrm{C}$ for $40 \mathrm{~h}$ under inert atmosphere. It was cooled, filtered through diatomaceous earth, extracted with ethyl acetate. The organic phase was washed with brine, dried over $\mathrm{Na}_{2} \mathrm{SO}_{4}$ and filtered. The solvent was removed in vacuum and the residual mass was purified by column chromatography (hexane/EtOAc, 97:3 v/v) to give $E-3$ (98 mg, 71\%). 
Cinnamates 3, 8, 9, 10 and 11; General procedure in water

A mixture of $\mathrm{Pd}(\mathrm{OAc})_{2}(11.2 \mathrm{mg}, 0.05 \mathrm{mmol})$, enoate $(Z-1,300 \mathrm{mg}, 1.5 \mathrm{mmol})$, iodobenzene $(2,102 \mathrm{mg}$, $0.5 \mathrm{mmol})$ and $\mathrm{Et}_{3} \mathrm{~N}(0.208 \mathrm{~mL}, 1.5 \mathrm{mmol})$ in $\mathrm{H}_{2} \mathrm{O}(10 \mathrm{~mL})$ was stirred at $80{ }^{\circ} \mathrm{C}$ for $40 \mathrm{~h}$ under $\mathrm{N}_{2}$ atmosphere. The mixture was allowed to cool, $\mathrm{H}_{2} \mathrm{O}(10 \mathrm{~mL})$ was added and it was extracted with EtOAc. The organic phase was washed with brine, dried over $\mathrm{Na}_{2} \mathrm{SO}_{4}$ and filtered through diatomaceous earth. The solvent was removed in vacuum and the residual mass was purified by column chromatography (hexane/EtOAc, 97:3 v/v) to give $E-3$ (66 mg, 48\%).

(S,E)-Ethyl 3-(2,2-dimethyl-1,3-dioxolan-4-yl)-3phenylacrylate $(E-3)$

Compound $E-\mathbf{3}$ was obtained as a yellow oil after purification by flash chromatography (EtOAc/hex 3:97 v/v); IR (KBr) vmax $/ \mathrm{cm}^{-1} 1727 \mathrm{~cm}^{-1} ;{ }^{1} \mathrm{H}$ NMR $(400 \mathrm{MHz}$, $\left.\mathrm{CDCl}_{3}\right) \delta$ 7.40-7.31 (3H, m), 7.19-7.13 (2H, m), $6.29(1 \mathrm{H}$, d, $J 1.5 \mathrm{~Hz}), 4.83(1 \mathrm{H}, \mathrm{td}, J 7.4,1.5 \mathrm{~Hz}), 4.06-3.92(3 \mathrm{H}$, m), $3.67(1 \mathrm{H}, \mathrm{dd}, J 8.1,7.6 \mathrm{~Hz}), 1.47(3 \mathrm{H}, \mathrm{s}), 1.43(3 \mathrm{H}$, s), $1.06(3 \mathrm{H}, \mathrm{t}, J 7.1 \mathrm{~Hz}) ;{ }^{13} \mathrm{C} \mathrm{NMR}\left(101 \mathrm{MHz}, \mathrm{CDCl}_{3}\right)$ $\delta 165.9,155.3,137.0,128.2,128.2,127.6,117.0,110.5$, 78.8, 68.8, 60.0, 26.3, 25.9, 14.0. MS, $m / z: 276\left[\mathrm{M}^{+}\right]$; HRMS (ESI) calcd for $\mathrm{C}_{16} \mathrm{H}_{20} \mathrm{NaO}_{4}[\mathrm{M}+\mathrm{Na}] 299.1259$, found: 299.1273 .

(S,Z)-Ethyl 3-(2,2-dimethyl-1,3-dioxolan-4-yl)-3phenylacrylate $(Z-3)$

Compound $E-3$ was obtained as a pale yellow oil after purification by flash chromatography (EtOAc/hex 2:98 v/v); ${ }^{1} \mathrm{H}$ NMR (400 MHz, $\left.\mathrm{CDCl}_{3}\right) \delta 7.43-7.28(5 \mathrm{H}, \mathrm{m})$, $6.00-5.96(1 \mathrm{H}, \mathrm{m}), 5.95(1 \mathrm{H}, \mathrm{d}, J 1.2 \mathrm{~Hz}), 4.49(1 \mathrm{H}$, t, $J 8.0 \mathrm{~Hz}), 4.21(2 \mathrm{H}, \mathrm{q}, J 7.1 \mathrm{~Hz}), 3.83(1 \mathrm{H}, \mathrm{dd}, J 8.2$, $6.8 \mathrm{~Hz}), 1.37(3 \mathrm{H}, \mathrm{s}), 1.31(3 \mathrm{H}, \mathrm{t}, J 7.1 \mathrm{~Hz}), 1.21(3 \mathrm{H}$, s); ${ }^{13} \mathrm{C}$ NMR $\left(101 \mathrm{MHz}, \mathrm{CDCl}_{3}\right) \delta 165.9,159.2,138.2$, $128.7,128.5,127.8,120.7,110.2,74.0,69.7,60.5,25.6$, 24.8, 14.4; HRMS (ESI) calcd for $\mathrm{C}_{16} \mathrm{H}_{20} \mathrm{NaO}_{4}[\mathrm{M}+\mathrm{Na}]$ 299.1259, found:299.1242.

\section{Dimethyl 2-phenylfumarate $(E-8)^{15}$}

Compound $E-\mathbf{8}$ was obtained as a pale yellow oil after purification by flash chromatography (EtOAc/hex 3:97 v/v); ${ }^{1} \mathrm{H}$ NMR $\left(500 \mathrm{MHz}, \mathrm{CDCl}_{3}\right) \delta$ 7.39-7.35 $(3 \mathrm{H}, \mathrm{m})$, 7.26-7.22 (2H, m), $7.02(1 \mathrm{H}, \mathrm{s}), 3.80(3 \mathrm{H}, \mathrm{s}), 3.60(3 \mathrm{H}, \mathrm{s})$; ${ }^{13} \mathrm{C} \mathrm{NMR}\left(101 \mathrm{MHz}, \mathrm{CDCl}_{3}\right) \delta 166.8,165.6,144.3,133.8$, $128.8,128.7,128.6,127.9,52.9,51.9$.
Dimethyl 2-phenylmaleate $(Z-8)^{15}$

Compound Z-8 was obtained as a pale yellow oil after purification by flash chromatography (EtOAc/hex 5:95 v/v). ${ }^{1} \mathrm{H} \mathrm{NMR}\left(400 \mathrm{MHz}, \mathrm{CDCl}_{3}\right) \delta$ 7.50-7.46 (2H, m), 7.44-7.36 $(3 \mathrm{H}, \mathrm{m}), 6.32(1 \mathrm{H}, \mathrm{s}), 3.95(3 \mathrm{H}, \mathrm{s}), 3.79(3 \mathrm{H}, \mathrm{s}) .{ }^{13} \mathrm{C} \mathrm{NMR}$ $\left(126 \mathrm{MHz}, \mathrm{CDCl}_{3}\right) \delta 168.3,165.4,149.0,133.1,130.6$, 129.0, 126.7, 126.7, 117.1, 117.0, 52.7, 52.7, 52.1, 52.0.

(E)-Ethyl 5-methyl-3-phenylhex-2-enoate (9) ${ }^{16}$

Compound 9 was obtained as a pale yellow oil after purification by flash chromatography (hexane). NMR $\left(400 \mathrm{MHz}, \mathrm{CDCl}_{3}\right) \delta$ 7.46-7.31 (5H, m), $6.04(1 \mathrm{H}, \mathrm{s}), 4.20$ $(2 \mathrm{H}, \mathrm{q}, J 7.1 \mathrm{~Hz}), 3.07(2 \mathrm{H}, \mathrm{d}, J 7.3 \mathrm{~Hz}), 1.71-1.58(1 \mathrm{H}$, $\mathrm{m}), 1.31(3 \mathrm{H}, \mathrm{t}, J 7.1 \mathrm{~Hz}), 0.87(6 \mathrm{H}, \mathrm{d}, J 6.7 \mathrm{~Hz})$.

(E)-Methyl 3-phenylbut-2-enoate (10) ${ }^{16}$

Compound $\mathbf{1 0}$ was obtained as a pale yellow oil after purification by flash chromatography (EtOAc/hex 1:99 v/v). ${ }^{1} \mathrm{H}$ NMR (400 MHz, $\left.\mathrm{CDCl}_{3}\right) \delta$ 7.51-7.42 (2H, m), 7.41-7.33 (3H, m), $6.14(1 \mathrm{H}, \mathrm{d}, J 1.3 \mathrm{~Hz}), 3.75(3 \mathrm{H}, \mathrm{s})$, $2.58(3 \mathrm{H}, \mathrm{d}, J 1.3 \mathrm{~Hz})$.

Methyl 3,3-diphenylacrylate (11) ${ }^{16}$

Compound $\mathbf{1 1}$ was obtained as a pale yellow oil after purification by flash chromatography (EtOAc/hex 1:99 v/v). ${ }^{1} \mathrm{H} \mathrm{NMR}\left(400 \mathrm{MHz}, \mathrm{CDCl}_{3}\right) \delta$ 7.42-7.27 (8H, m), 7.23-7.18 $(2 \mathrm{H}, \mathrm{m}), 6.37(1 \mathrm{H}, \mathrm{s}), 3.61(3 \mathrm{H}, \mathrm{s})$.

\section{Supplementary Information}

Supplementary data are available free of charge at http://jbcs.sbq.org.br as PDF file.

\section{Acknowledgments}

The authors thank CAPES, FAPERJ, FAPESP, FINEP, $\mathrm{CNPq}$ and the program of Oncobiology-UFRJ for financial support and fellowships. We thank Meryellen M. de Oliveira for helping in some reactions.

\section{References}

1. Heck, R. F.; J. Am. Chem. Soc. 1968, 90, 5518.

2. Mizoroki T.; Mori, K.; Ozaki, A.; Bull. Chem. Soc. Jpn. 1971, 44, 581.

3. Heck, R. F.; Nolley Jr., J. P.; J. Org. Chem. 1972, 37, 2320.

4. Beletskaya, I. P.; Cheprakov, A. V.; Chem. Rev. 2000, 100, 3009. 
5. Alonso, F.; Beletskaya, I. P.; Yus, M.; Tetrahedron 2005, 61, 11771; Heravi, M. M.; Fazeli, A.; Heterocycles 2010, 81, 1979; Lamblin, M.; Nassar-Hardy, L.; Hierso, J. C.; Fouquet, E.; Felpin, F. X.; Adv. Synth. Catal 2010, 352, 33; Knowles, J. P.; Org. Biomol. Chem. 2007, 5, 31; Bellina, F.; Chiappe, C.; Molecules 2010, 15, 2211; Ruan, J.; Xiao, J.; Acc. Chem. Res. 2011, 44, 614.

6. Samanta, S.; Mohapatra, H.; Jana, R.; Ray, J. K.; Tetrahedron Lett. 2008, 49, 7153; Madin, A.; O’Donnell, C. J.; Oh, T.; Old, D. W.; Overman, L. E.; Sharp, M. J.; J. Am. Chem. Soc. 2005, 127, 18054; Ashimori, A.; Bachand, B.; Calter, M. A.; Govek, S. P.; Overman, L. E.; Poon, D. J.; J. Am. Chem. Soc. 1998, 120,6488 .

7. Taylor, J. G.; Correia, C. R. D.; J. Org. Chem. 2011, 76, 857; Mieczyńska, E.; Gniewek, A.; Pryjomska-Ray, I.; Trzeciak, A. M.; Grabowska, H.; Zawadzki, M.; Appl. Catal. A: General 2011, 393, 195; Pastre, J. C.; Correia, C. R. D.; Org. Lett. 2006, 8, 1657; Botella, L.; Nájera, C.; J. Org. Chem. 2005, 70, 4360; Kondolff, I.; Doucet, H.; Santelli, M.; Tetrahedron Lett. 2003, 44, 8487; Caló, V.; Nacci, A.; Monopoli, A.; Laera, S.; Cioffi, N.; J. Org. Chem. 2003, 68, 2929; Moreno-Mañas, M.; Pérez, M.; Pleixats, R.; Tetrahedron Lett. 1996, 37, 7449; Gürtler, C.; Buchwald, S. L.; Chem. Eur. J. 1999, 5, 3107; Cacchi, S.; Fabrizi, G.; Goggiamani, A.; Sferrazza, A.; Synlett 2009, 8, 1277; Ciattini, P. G.; Ortar, G.; Synthesis 1986, 70.

8. Takeda, T.; Modern Carbonyl Olefination: Methods and Applications; Wiley-VCH, Weinheim, 2004.

9. Breit, B.; Schmidt, Y.; Chem. Rev. 2008, 108, 2928; Negishi, E.; Huang, Z.; Wang, G.; Mohan, S.;Wang, C.; Hattori, H.; Acc. Chem. Res. 2008, 41, 1474.

10. Connon, S. J.; Blechert, S.; Angew. Chem. Int. Ed. 2003, 42, 1900; Grubbs, R. H.; Chang, S.; Tetrahedron 1998, 54, 4413.

11. Schmidt, Y.; Breit, B.; Chem. Eur. J. 2011, 17, 11780; Pospisil, J.; Pospisil, T. Marko, I. E.; Org. Lett. 2005, 7, 2373; Arefolov, A.; Langille, N. F.; Panek, J. S.; Org. Lett. 2001, 3, 3281; Ricci, A.; Blart, E.; Comes-Franchini, M.; Reginato, G.; Zani, P.; Pure Appl. Chem. 1996, 68, 679.

12. Fernandes, T. D.; Vaz, B. G.; Eberlin, M. N.; da Silva, A. J. M.; Costa, P. R. R.; J. Org. Chem. 2010, 75, 7085.

13. Ziegler, C. B.; Heck, R. F.; J. Org. Chem. 1978, 43, 2941.

14. Reaction using coumarin did not generate Heck adduct.

15. Jana, R.; Tunge, J. A.; J. Org. Chem. 2011, 76, 8376; Li, J.; Jiang, H.; Jia, L.; Synth. Commun. 1999, 29, 3733.

16. Pastre, J. C.; Correia, C. R. D. Adv. Synth. Catal. 2009, 351, 1217; Ruan, J.; Li, X.; Saidi, O.; Xiao, J.; J. Am. Chem. Soc. 2008, 130, 2424; Mantilli, L.; Gérard, D.; Torche, S.; Besnard, C.; Mazet, C.; Chem. Eur. J. 2010, 16, 12736;
17. Gaussian 09, Revision B.1, Frisch, M. J.; Trucks, G. W.; Schlegel, H. B.; Scuseria, G. E.; Robb, M. A.; Cheeseman, J. R.; Scalmani, G.; Barone, V.; Mennucci, B.; Petersson, G. A.; Nakatsuji, H.; Caricato, M.; Li, X.; Hratchian, H. P.; Izmaylov, A. F.; Bloino, J.; Zheng, G.; Sonnenberg, J. L.; Hada, M.; Ehara, M.; Toyota, K.; Fukuda, R.; Hasegawa, J.; Ishida, M.; Nakajima, T.; Honda, Y.; Kitao, O.; Nakai, H.; Vreven, T.; Montgomery, Jr., J. A.; Peralta, J. E.; Ogliaro, F.; Bearpark, M.; Heyd, J. J.; Brothers, E.; Kudin, K. N.; Staroverov, V. N.; Kobayashi, R.; Normand, J.; Raghavachari, K.; Rendell, A.; Burant, J. C.; Iyengar, S. S.; Tomasi, J.; Cossi, M.; Rega, N.; Millam, N. J.; Klene, M.; Knox, J. E.; Cross, J. B.; Bakken, V.; Adamo, C.; Jaramillo, J.; Gomperts, R.; Stratmann, R. E.; Yazyev, O.; Austin, A. J.; Cammi, R.; Pomelli, C.; Ochterski, J. W.; Martin, R. L.; Morokuma, K.; Zakrzewski, V. G.; Voth, G. A.; Salvador, P.; Dannenberg, J. J.; Dapprich, S.; Daniels, A. D.; Farkas, Ö.; Foresman, J. B.; Ortiz, J. V.; Cioslowski, J.; Fox, D. J.; Gaussian, Inc., Wallingford CT, 2009.

18. Chen, P.; Angew. Chem. Int. Ed. 2003, 42, 2832; Eberlin, M. N.; Eur. J. Mass Spectrom. 2007, 13, 19; Coelho, F.; Eberlin, M. N.; Angew. Chem. Int. Ed. 2011, 50, 5261; Santos, L. S.; J. Braz. Chem. Soc. 2011, 22, 1827; Santos, L. S. Reactive Intermediates, MS Investigations in Solution; Wiley-VCH, Weinheim, 2010; Regiani, T.; Santos, V. G.; Godói, M. N.; Vaz, B. G.; Eberlin, M. N.; Coelho, M. N.; Chem. Commun. 2011, 47, 6593; Camargo, M. A.; Neves, A.; Bortoluzzi, A. J.; Szpoganicz, B.; Fischer, F. L.; Terenzi, H.; Serra, O. A.; Santos, V. G.; Vaz, B. G. Eberlin, M. N. Inorg. Chem. 2010, 49, 6013.

19. Sabino, A. A.; Machado, A. H. L.; Correia, C. R. D.; Eberlin, M. N.; Angew. Chem. Int. Ed. 2004, 43, 2514; Stefani, H. A.; Pena, J. M.; Gueogjian, K.; Petragnani, N.; Vaz, B. G.; Eberlin, M. N.; Tetrahedron Lett. 2009, 50, 5589; Oliveira, F. F. D.; dos Santos, M. R.; Lalli, P. M.; Schmidt, E. M.; Bakuzis, P.; Lapis, A. A. M.; Monteiro, A. L.; Eberlin, M. N.; Neto, B. A. D.; J. Org. Chem. 2011, 76, 10140; Buarque, C. D.; Pinho, V. D.; Vaz, B. G.; Eberlin, M. N.; da Silva, A. J. M.; Costa, P. R. R.; J. Organomet. Chem 2010, 695, 2062; Vikse, K. L.; Henderson, M. A.; Oliver, A. G.; Chem. Commun. 2010, 46, 7412; Deprez, N. R.; Sanford, M. S.; J. Am. Chem. Soc. 2009, 131, 11234.

Submitted: August 1, 2012 Published online: March 19, 2013

FAPESP has sponsored the publication of this article. 